\title{
EFFECT OF NATURAL DISASTER-BASED VIDEO MEDIA TO INCREASE STUDENT'S ENVIRONMENTAL SENSITIVITY
}

\author{
AMINAH ZUHRIYAH ${ }^{1 *}$, I MADE ASTRA ${ }^{2}$ AND YUFIARTI ${ }^{3}$ \\ ${ }^{1}$ The Education of Population and Environmental Program, State University of Jakarta. ${ }^{2}$ Physics Program, State University \\ of Jakarta. ${ }^{3}$ Dean of Psychology, State University of Jakarta.
}

*Corresponding author: aminahzuhriyah2808@gmail.com

Submitted final draft: 30 October $2020 \quad$ Accepted: 15 November $2020 \quad$ http://doi.org/10.46754/jssm.2021.08.018

\begin{abstract}
This article discusses the benefits of technology on learning media for environmental education. The research objective was to see the impact of natural disaster video media on increasing student sensitivity. The research method used was experimental with research samples from two groups of 30 students in Accounting and Financial Institutions at SMK Yatindo Bekasi. The instrument used was a questionnaire with multiple choices. Data analysis used inferential statistics with SPSS Version 22. The test results on the normality test for the experimental class and control class obtained a count sig value $=0.200>0.05 \mathrm{sig}$ table with normal distribution. The homogeneity test obtained a sig value of $0.58>0.05 \mathrm{sig}$. table, the results of the recommendations are equally homogenous variant groups. In the hypothesis test, the t-test value was obtained $=5.970>2.002$ or sig $(2$-tailed $)=0.000<$ sig table $=0.05$, the results of the students' environmental sensitivity score in the experimental class were higher than the control class. It happens that students can increase environmental sensitivity if facilitated by video media of natural disasters, because it is necessary to instill environmental sensitivity.
\end{abstract}

Keywords: Video media, natural disasters, environmental sensitivity.

\section{Introduction}

Environmental sensitivity can be interpreted as an environmental response to environmental changes (Basso, 2000). Environmental sensitivity is also an empathic view or understanding of the environment (Sivek, 2010). Environmental sensitivity is an individual characteristic to perceive the environment with empathy (Cheng \& Homer, 2014). Ferguson, et al., (2020) stated that empathy is an effective component (sharing experiences, feeling what you feel), a cognitive component (taking perspective, putting yourself in the position of others) and a deliberate component (compassion and to have intentions). Hungerford and Volk (2013) say that environmental sensitivity is a behavioral variable related to environmental education which has the objectives of the agreement at the 1978 Tbilisi conference, namely: a. Awareness: helping individuals and social groups gain awareness and sensitivity to problems related to the environment; b. Sensitivity: helps individuals and social groups gain experience and understand basic environmental problems; c. Attitudes: helping individuals and groups gain values and feelings about the environment and motivation to support activities to improve and protect the environment; d. Skills: helping individuals and groups acquire skills to cope with and solve environmental problems; e. Participation: provide opportunities for individuals and social groups to be actively involved in working to solve environmental problems. The role of education is important in disseminating information, especially for students, because they are the younger generation who will take advantage of and manage this environment. It is necessary for future generations to be equipped with knowledge of environmental education in order to have a responsible attitude and be able to participate in environmental problems (Feszterova et al., 2015). In addition, the goal of environmental education is to create individuals who are sensitive to environmental problems (Alaydin et al., 2014). Environmental education is important to promote environmental sensitivity among the community (Hassan et al., 2011). In previous research conducted by Sivek (2010) 
that the main factor for instilling long-term environmental sensitivity is important to have learning experiences outdoors or visiting natural areas. Referring to these findings, researchers will continue research related to environmental sensitivity, to find out whether environmental sensitivity will grow in students by interacting through social media (videos based on natural disasters) in a limited space (class).

Environmental education objectives above e that environmental education provides knowledge about the values of positive attitudes and behaviors, skills and participation to be active in environmental problem-solving activities. One of the environmental problems caused by nature is natural disaster. After a disaster, there will be a lot of damage in various places which causes complex impacts on the social and environmental systems (Davidsson, 2020). Shoji et al., (2020) stated that natural disasters cause many human lives to be lost. Disasters that occurred between 1996 and 2015, caused
135 million lives to be lost, of which $56 \%$ were victims of natural disasters. Natural disasters can also have a negative impact on the physical, biological and social environment of human life (Sangha et al., 2020). Based on information from world organizations, in the last 20 years (19982017), approximately 1.3 million people died and 4.4 billion people were affected by natural disasters (Research Center for Epidemiology of Disasters) and the latest news from the World Health Organization reported that an average of about 90,000 people died out of 160 million people affected by natural disasters each year (Sangha et al., 2020). In Indonesia, between January 1 and December 23 2019, 3,721 natural disasters occurred, including forest and land fires, floods, landslides, droughts, earthquakes, tidal waves, volcanic eruptions, tornadoes (Luthfia Ayu Azanella, 2019). Hidalgo, et al., (2019) described natural disasters in table 1, as follows:

Natural disasters are studied by students

Table 1: Classification of natural disasters (Hidalgo, et al., 2019).

\begin{tabular}{llll}
\hline Classification of Natural Disasters & & \\
\hline Geophysical & Hydrologic & Meteorological & Climatologic \\
- Earthquake & • Flood & • Storm & • Extreme temperature \\
$\begin{array}{l}\text { Ground shaking } \\
\text { Tsunami }\end{array}$ & 1. General flood & 1. Tropical cyclone & 1. Heatwave \\
- Volcano & 2. Flash Flood & 2. Extratropical & 2. Coldwave Frost \\
Volcano eruption & 3. Storm surge/ & Cyclone (winter storm) & 3. Extreme winter \\
- Mass movement (dry) & coastal flood & a. Convective storm & conditions Snow \\
• Mass movement & Thunderstorm/ & pressure Icing \\
1. Rockfall & (wet) & lightning Snowstorm/ & Freezing rain \\
2. Landslide & 1. Rockfall & blizzard Sandstorm/ & Debris avalanche \\
Mudslide Lahar & 2. Landslide Debris & dust storm Generic & • Drought \\
Debris flow & flood & (severe) storm & • Wildfire \\
3. Avalanche & 3. Avalanche & Tornado Orographic & 1. Forest fire \\
Snow avalanche & Snow avalanche & storm (strong winds) & 2. Landfire \\
$\begin{array}{l}\text { Debris avalanche } \\
\text { 4. Subsidence }\end{array}$ & Debris avalanche & b. Local storm & \\
Sudden subsidence & 4. Subsidence & & \\
Long-lasting & Sudden subsidence & & \\
subsidence & Long-lasting & & \\
& subsidence & & \\
\hline
\end{tabular}


in natural science subjects in the experimental group and the control group. A natural disaster is an event, so researchers needed to show videos of natural disasters to experimental group students to find out the impact of natural disaster video media to increase students' environmental sensitivity. According to some experts, videos can be used to promote learning materials, (Sun \& Hsing, 2007). Video is an influential teaching tool to attract public attention and has the potential to motivate learning (Nasir, et al., 2017). ideo in education has been widely used as an innovative solution that can meet the needs of (1) increasing knowledge, and (2) as a method for evaluating technical skills and competencies (Green L et al., 2019). Instructional video media is a very effective educational tool (D'Aquila et al., 2019). Merkt et al.,(2011) stated that video is an integral component of daily environmental education for students, but from the perspective of educational psychology, the status of video as an effective learning medium cannot be doubted. The use of videos can help and facilitate learning by modifying behavior, so as to improve their social and communication skills (Saiman et al., 2013). In addition, the advantage of using instructional videos is that they can show a link between animated screenshots and real-life task execution (Van der Meij et al., 2014). According to the opinion of the experts above, video media is a communication tool that uses an audiovisual component that can become a modern learning medium, while providing understanding and knowledge for its users. Referring to previous research conducted by Fraustino et al., (2018) immersive visual technology media can be an effective tool to attract viewers to content and increase their positive attitude towards it. Knowledge on natural disasters is very important for crisis audiences to know during the disaster recovery phase.

\section{Materials and methods}

This research uses a quantitative approach and experimental methods. The research population comprises Vocational High Schools (SMK) in Mustika Jaya Village, Bekasi, Odd
Academic Year 2019/2020. The research sample was randomly selected using purposive cluster random sampling among students of SMK Yatindo class X-2 (30 students consisting of 25 girls and 5 boys) and class X-1 (30 students consisting of 26 girls and 4 boys). Their characteristics are young people who will become future leaders in making policies and protecting the environment. The experimental class was selected based on the learning outcomes of natural disasters the students previously studied. Learning outcomes averaged 118.5 (low score) in the experimental class, while the group of students with an average 124.5 (high score) are in the control class. This learning strategy will use natural disaster-based video media. This learning is only followed by Class X-2 students as an experimental group with the Discovery learning method and in groups because they are assigned to search for videos based on natural disasters on YouTube and the video will be displayed in front of the class. Only a few students have tried to find videos on YouTube. So through the video search process, students are formed learning groups so that they can share with each other. Members help and encourage each other to learn and share knowledge (Laal, 2012).

In the learning process to show the video to an audience, students must have supporting technology that has been prepared by the school, such as: laptops, projectors, speakers, video storage flash drives and environmental situations. After the presentation of the assignment was complete, the two groups of students (experimental and control) were given an environmental sensitivity instrument test. To measure environmental sensitivity, Metzger et al. (2010) stated that environmental sensitivity can be measured using the Environmental Sensitivity Questionnaire (ESQ) with a Likert scale. The basic structure of the ESQ follows the taxonomic goals of education in the affective domain. Its objectives areas; (a) Receiving (awareness, desire to receive, control or choose attention); (b) Responding (agreed response, willingness to respond, satisfaction 
with the response); and (c) Appraisal (value acceptance, value preference, commitment to value explanation). Of the three objectives, as a grid and indicator aspect, an environmental sensitivity instrument was made in this study. The environmental sensitivity instrument grid and sample questions in this study are presented in Table 2, as follows:

Table 2: Environmental sensitivity instrument grid and sample problems

\begin{tabular}{|c|c|c|c|}
\hline No. & Aspect & Indicator & Problems Example \\
\hline 1 & $\begin{array}{l}\text { How to accept the } \\
\text { natural and social } \\
\text { environment }\end{array}$ & $\begin{array}{l}\text { The attitude of accepting } \\
\text { God's creation. } \\
\text { The attitude of accepting the } \\
\text { existence of others. }\end{array}$ & $\begin{array}{l}\text { I accept and believe that this earth was } \\
\text { created. } \\
\text { I accept friends' ideas on mutual } \\
\text { consideration. }\end{array}$ \\
\hline 2 & How to respond & $\begin{array}{l}\text { Attitude to respond to natural } \\
\text { or social environmental } \\
\text { situations. }\end{array}$ & $\begin{array}{l}\text { I am concerned that the earth is currently } \\
\text { experiencing global warming that has not } \\
\text { been resolved, but natural disasters often } \\
\text { occur in various countries. } \\
\text { I respond to the government's } \\
\text { recommendation in an effort to save } \\
\text { energy in daily needs. }\end{array}$ \\
\hline 3 & How to judge & $\begin{array}{l}\text { Behavior of judging other } \\
\text { people's work. }\end{array}$ & $\begin{array}{l}\text { I will congratulate friends who pass with } \\
\text { the best grades. }\end{array}$ \\
\hline
\end{tabular}

The environmental sensitivity instrument was made of 30 validated questions. And each question consists of 5 answer choices, namely: Strongly agree $=5$ points, Agree $=4$ points, Doubt $=3$ points, Disagree $=2$ points, and Strongly disagree $=1$ points. Data obtained from the environmental sensitivity test of the experimental group students (class X-2) and the control group (class $\mathrm{X}-1$ ) will be tested for hypotheses ( $t$ test) (a) normality test using Kolmogorov-Smirnov, the test criteria: if the significance value (sig) is greater than 0.05 then the research data is normally distributed and if the sig is smaller than 0.05 , the research data is not normally distributed. (b) the homogeneity test uses the Levene test, the test criteria: if the sig $<0.05$, then it is stated that the variance of the two data groups is not the same or not homogeneous and if the calculated sig $>0.05$, it is stated that the variance of the two data groups is equal or homogeneous.

Next, the hypothesis test is carried out using the $t$ test, conducted to determine and check the effectiveness of the treatment, the test criteria: Accept $\mathrm{H}_{0}$ if: t-count $<\mathrm{t}$-table or Reject $\mathrm{H}_{0}$ if: t-count $>$ t-table.

\section{Result}

After the learning process the researcher evaluates the learning outcomes, by taking the data obtained from the environmental sensitivity instrument test of students in the experimental class and the control class, the data is collected and grouped. Furthermore, the data is arranged in the form of a pie chart (figure 1).

\section{Descriptive Data}

Based on Figure 1, the data obtained from the environmental sensitivity instrument test were from 30 questions with a total of 150 responses, carried out by 30 respondents from the experimental group (class X-2). In the pie chart, several colors appear, this indicates the number of scores that students obtained from the environmental sensitivity instrument test. To read the results of a pie chart, starting from the smallest value or color grid (blue and green) with 3 respondents, a score of $125-127$ or percentage of 83-84 is considered sufficient. In colors (light brown, purple, yellow, red, Tosca blue, gray, light blue, dark green, orange, and light purple) with 24 respondents, a score 


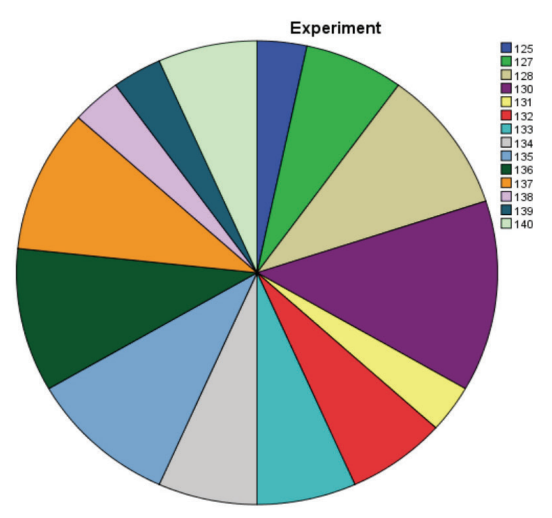

Figure 1: Percentage of experimental group statistical data

between 128 - 138 or a percentage of $85-92$ is considered good. In Tosca blue, and light green, with 3 respondents, a score between 139 - 140 or percentage of 92.5 - 93 is stated in the very good category. Based on the above calculations, of the 30 student respondents in the experiment group (class X-2) can pass the minimum completeness criteria value $=75$ and are included in the very satisfying category because $90 \%$ of students get a score of 85 .

In Figure 2, the data obtained from the environmental sensitivity instrument test were 30 questions with a total of 150 correct answers, carried out by 30 respondents from the control class student group. In the pie chart, several colors appear, this indicates the number of scores that students obtained from the environmental sensitivity instrument test. To read the results of a pie chart or Pie Chat image, starting from the smallest value or color circle (blue, green, light brown, dark purple, yellow, red, Tosca blue, gray, light blue, and dark green)

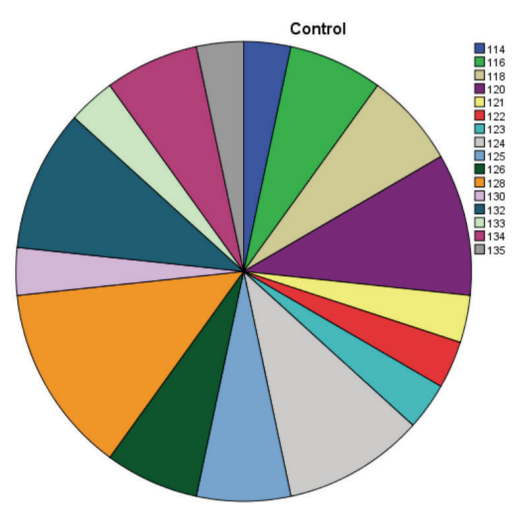

Figure 2: Percentage of c ontro group statistical data

with 18 respondents, a score of $114-125$ or a value of $78-84$, which is considered sufficient. Inorange, light purple, solid Tosca blue, light green, purple, and dark gray 12 respondents scored between 126 and 135 or a value of 85 - 90, which is in the good category. Based on the above calculations, all student respondents in the control group (class X-1), achieved the minimum completeness criteria value $=75$, and are included in the satisfactory category because only $40 \%$ of students get a score of 85 .

\section{Calculation of Data Analysis}

a. Normality test:

Based on Table 3, from the results of the calculation of the normality test with the Kolmogorov-Smirnov test for the experimental class (class X-2) and the control class (class $\mathrm{X}-1)$, the value $(\mathrm{sig})=0.200$ means that the value (sig) is greater than the value (sig) table 0.05 . then the result stated that the data from the two groups were normally distributed.

Table 3 : Tests of normality

\begin{tabular}{|c|c|c|c|c|c|c|c|}
\hline & \multirow{2}{*}{ Class } & \multicolumn{3}{|c|}{ Kolmogorov-Smirnov ${ }^{\mathrm{a}}$} & \multicolumn{3}{|c|}{ Shapiro-Wilk } \\
\hline & & Statistic & Df & Sig. & Statistic & Df & Sig. \\
\hline \multirow{2}{*}{$\begin{array}{l}\text { Environmental } \\
\text { Sensitivity }\end{array}$} & Experiment & .110 & 30 & $.200^{*}$ & .965 & 30 & .409 \\
\hline & Control & .107 & 30 & $.200^{*}$ & .965 & 30 & .410 \\
\hline
\end{tabular}

*. This is a lower bound of the true significance.

a. Lilliefors Significance Correction 


\section{b. Homogeneity Test:}

The results of the homogeneity test using the Levene test showed that the sig value of 0.058 was greater than the sig table value of 0.05 , meaning that the variants of the two groups were declared homogeneous. The results can be seen in table 4, as follows:

\section{Hypothesis test}

Furthermore, testing the hypothesis ( $\mathrm{t}$ test) using independent samples test is carried out if the data analysis test meets the requirements. The results of hypothesis testing in this study obtained the test value of $t=5.970>2.002$ or $\operatorname{sig}(2$ - tailed $)=0.00<0.05$ (sig table), then the rejected hypothesis is $\mathrm{H}_{0}$, where $\mathrm{t}_{\text {count }}>\mathrm{t}_{\text {table }_{\text {e }}}$, it is concluded that there is difference in students' environmental sensitivity scores between the experimental class (class X-2) who learned using video media based on natural disasters and the control class students (class X-1) without treatment. The results of hypothesis testing ( $t$ test) with the Independent Samples Test can be seen in Table 4, as follows:

\section{Discussion}

This research involves the use of natural disasterbased video media in environmental education to find out how students respond to environmental damage caused by natural disasters. Based on the results of this study, there were differences in students' environmental sensitivity scores between the experimental group (class X-2) who learned using video media based on natural disasters and students in the control group (class X-1) without treatment. The difference in environmental sensitivity scores an average of 133.10 (experimental group) and an average of 125.20 (control group). The results can be seen in Table 5, as follows:

Table 4 : Independent samples test

\begin{tabular}{|c|c|c|c|c|c|c|c|c|c|c|}
\hline & & \multicolumn{2}{|c|}{$\begin{array}{l}\text { Levene's Test } \\
\text { for Equality } \\
\text { of Variances }\end{array}$} & \multicolumn{5}{|c|}{ t-test for Equality of Means } & & \\
\hline & & $\mathrm{F}$ & Sig. & $\mathrm{T}$ & df & $\begin{array}{l}\text { Sig. } \\
(2- \\
\text { tailed) }\end{array}$ & $\begin{array}{c}\text { Mean } \\
\text { Difference }\end{array}$ & $\begin{array}{l}\text { Std. Error } \\
\text { Difference }\end{array}$ & \multicolumn{2}{|c|}{$\begin{array}{c}95 \% \\
\text { Confidence } \\
\text { Interval of the } \\
\text { Difference }\end{array}$} \\
\hline & & & & & & & & & Lower & Upper \\
\hline \multirow{2}{*}{$\begin{array}{l}\text { Environ- } \\
\text { mental } \\
\text { sensitivity }\end{array}$} & $\begin{array}{l}\text { Equal } \\
\text { variances } \\
\text { assumed }\end{array}$ & 3.752 & .058 & 5.970 & 58 & .000 & 7.900 & 1.323 & 5.251 & 10.549 \\
\hline & $\begin{array}{l}\text { Equal } \\
\text { variances not } \\
\text { assumed }\end{array}$ & & & 5.970 & 51,904 & .000 & 7.900 & 1.323 & 5.244 & 10.556 \\
\hline
\end{tabular}

Table 5: Data descriptive statistics

\begin{tabular}{|c|c|c|c|}
\hline & & Experiment & Control \\
\hline \multirow[t]{2}{*}{$\mathbf{N}$} & Valid & 30 & 30 \\
\hline & Missing & 30 & 30 \\
\hline \multicolumn{2}{|c|}{ Mean } & 133.10 & 125.20 \\
\hline \multicolumn{2}{|c|}{ Minimum } & 125 & 114 \\
\hline \multicolumn{2}{|c|}{ Maximum } & 140 & 135 \\
\hline
\end{tabular}


From these results it is evident that the impact of natural disaster-based video media can increase environmental sensitivity in the experimental group (class X-2). This study found three findings, namely: 1) the emergence of a positive view of students on social media (YouTube) in seeking new knowledge (videos based on natural disasters to increase their knowledge and skills, 2) the desire of students to learn about natural disasters and their mitigation, and 3) the important role of social media, through videos based on natural disasters, to build environmental sensitivity of students. The first finding is that there is a positive view of students on social media (youtube), after students are involved in looking for videos, so that students' knowledge and skills develop. Dehghani (2016) said that YouTube stores a lot of information and knowledge. YouTube is a social media resource that is widely used for professional purposes
(D’Aquila, et al., 2019).

For the second finding: students' curiosity to learn about natural disasters and their mitigation. By watching the natural disaster content on the video, students feel empathy, so they respond by asking questions. Empathy requires attention and cognitive effort (Ferguson et al., 2020). Cognitive empathy is sometimes referred to as literature on perspective taking (Moore et al., 2015). Kashdan et. al, (2020) says that curiosity is about seeking information and experiences for one's benefit by directing one's behavior and one of the most efficient and effective ways to obtain new information is by observing and interacting with the environment (communicating with others. To reduce the impact of these natural disasters, students must know how to mitigate natural disasters. The opinions of these natural disaster mitigation experts are shown in Table 6 as follows:

Table 6 : Natural disaster mitigation strategies

\begin{tabular}{cl}
\hline Disaster & \multicolumn{1}{c}{ Mitigation } \\
\hline Landslide & $\begin{array}{l}\text { Choi et al., (2013) said mitigating landslides by implementing the Landslip preventive } \\
\text { Measures program; and strengthen the soil slope factor. } \\
\text { Cotecchia et al.,(2016) landslide mitigation through multiscalar methods with the first phase, } \\
\text { characterization of landslides; second phase, recognition of the connection between the slope } \\
\text { factor and the process of instability. }\end{array}$ \\
\hline Flood & $\begin{array}{l}\text { Tamagnone, et al., (2020) said the ability of native rainwater harvesting techniques (RWHT) } \\
\text { to be used as a feasible solution for flood mitigation with rainwater harvesting techniques } \\
\text { (RWHT). }\end{array}$ \\
\hline Earthquake & $\begin{array}{l}\text { Titaya (2016) said there is knowledge of responding that affects the ability of citizens } \\
\text { during an earthquake and important information about regulations for earthquake resistant } \\
\text { buildings. }\end{array}$ \\
\hline A tsunami & $\begin{array}{l}\text { Samarasekara, et al., (2017) said that tsunami mitigation by building a tsunami warning } \\
\text { system. Canales, et. al. (2019) said tsunami mitigation with evacuation measures as an } \\
\text { important method to save lives.. }\end{array}$ \\
\hline Volcanic & $\begin{array}{l}\text { Gregg, et al., (2008) say immediately give a little warning about the potential for an early } \\
\text { eruption, and once an eruption begins it's time to respond, which means the security } \\
\text { community needs steps to be taken to reduce the impact of a sudden eruption. }\end{array}$ \\
\hline
\end{tabular}

The third finding, the researcher focuses more on the importance of the role of social media to always present environmental problems in order to build environmental sensitivity for students as millennials who tend to be involved in the digital world. Feszterova, et al, (2015) said that environmental problems provide students with experiences, thus enabling them to actively participate in environmental protection activities while promoting positive attitudes. What are the attitudes of students who tend to be involved in the digital world? In the digital age, 
social media has been recognized as a powerful "lens" that can expose the psychological state of people (Zou, et al., 2020). And people who prefer social media are likely to have high levels of disclosure. different selves (Zou, et al., 2020). Natural disaster videos displayed in the learning process can provide students with an expression of sensitivity to the environment through their attitudes and behavior. Disasters can have a physical and psychological impact on the people involved (Moa, et. al., 2018). It is important to instil environmental sensitivity for humans in interacting with the environment (Campo, 2017). Particularly for students as the current and future generation, they should be responsible for environmental development in a sustainable manner.

\section{Conclusion}

The use of digital technology can guide other activities. In environmental education learning, a strategy is needed to involve digital media technology, such as video media. Video media provides a clearer understanding of environmental problems because the current generation is more involved in activities with digital technology.Digital media technology can raise awareness on environmental problems that occur around them in order to realize that the environment needs to be cared for and preserved in a sustainable manner. environmental education into formal education and can be supported with social media. This is one way to instill environmental sensitivity in students, so that they gain knowledge, sensitivity, attitudes, skills and active participation in solving environmental problems. This knowledge can be implemented by students so that they can act wisely in utilizing the environment and being able to solve environmental problems (natural disasters) in a collaborative manner.

\section{Acknowledgements}

The author would like to thank Yatindo Bekasi Vocational High School (SMK) for the support in the research location, and the research supervisor, Professor Dr. I Made Astra, M.Sc along with Professor Dr. Yufiarti, M.Psy for the direction in this research.

\section{References}

Alaydin, Elif, Gulcin Demirel, Sureyya Altin, \& Ahmet Altin. (2014). Environmental knowledge of primary school students: Zonguldak (Turkey) example. Procedia Social and Behavioral Sciences, 141, 11501155.

Basso, F, E. Bove., S. Dumontet, A. Ferrara, M. Pisante, G. Quaranta, \& M. Taberner. (2000). Evaluating environmental sensitivity at the basin scale through the use of geographic information systems and remotely sensed data: An example covering the Agribasin Southern Italy. Catena, 40, 19-35.

Campo, Ainhoa Gonzalez Del. (2017). Mapping environmental sensitivity: A systematic online approach to support environmental assessment and planning. Environmental impact assessment Review, 66, 86-98.

Canales, Jorge Leon, Magdalena Vicuna del Rio, \& Alejandra Gubler. (2019). Increasing tsunami risk through intensive urban densification in metropolitan areas: A longitudinal analysis in Vina del Mar, Chile. International Journal of Disaster Risk Reduction, 41, 1-30.

Choi, K. Y., \& Raymond W. M. Cheung. (2013). Landslide disaster prevention and mitigation through works in Hong Kong. Journal of Rock Mechanics and Geotechnical Engineering, 5, 354-365.

Cotecchia, Federica, Francesca Santaloia, Piernicola Lollino, Claudia Vitone, Francesco Cafaro, \& Osvaldo Bottiglieri. (2016). Ageomechanical approach to landslide hazard assessment: The Multiscalar Method for Landslide Mitigation. Procedia Engineering, 158, 452-457.

D’Aquila, Jill M., Daphne Wang, \& Angela Mattia. (2019). Are instructor generated 
YouTube videos effective in accounting classes? A study of student performance, engagement, motivation, and perception. Journal of Accounting Education, 47, 6374.

Davidsson, Asa, (2020). Disasters as an opportunity for improved environmental conditions. International Journal of Disaster Risk Reduction, 48, 1-13.

Dehghani, Milad, Mojtaba Khorram Niaki, Iman Ramezani, \& Rasoul Sali. (2016). Evaluating the influence of YouTube advertising for attraction of young customers. Computers in Human Behavior, 59, 165-172.

Ferguson, Amanda M., C. Daryl Cameron, \& Michael Inzlicht. (2020). Motivational effects on empathic choices. Journal of Experimental Social Psychology, 90, 1-17.

Feszterova, Melania, \& Klaudia Jomova. (2015). Character of innovations in environmental education. Procedia Social and Behavioral Sciences, 197, 1697-1702.

Fraustino, Julia Daisy, Ji Young Lee, Sang Yeal Lee, \& Hongmin Ahn. (2018). Effects of $360^{\circ}$ video on attitudes toward disaster communication: Mediating and moderating roles of spatial presence and prior disaster media involvement. Public Relations Review, 44, 331-341.

Green, Jason, Visakha Suresh, Peter Bittar, Leila Ledbetter, MliS, Suhail K. Mithani, \& Alexander Allori. (2019). The utilization of video technology in surgical education: A systematic review. Journal of Surgical Research, 235, 171-180.

Gregg, C. E., B. F. Houghton, D. Paton, D. A. Swanson, R. Lachmane, \& W. J. Bonk. (2008). Hawaiian cultural influences on support for lava flow hazard mitigation measures during the January 1960 eruption of Kîlauea volcano, Kapoho, Hawai. Journal of Volcanology and Geothermal Research, 172, 300-307.
Hassan, Arba'at, \& Mohd Zaid Ismail. (2011). The infusion of Environmental Education (EE) in chemistry teaching and students' awareness and attitudes towards environment in Malaysia. Procedia Social and Behavioral Sciences, 15, 3404 -3409.

Hidalgo, Jorge, \& Amado Alejandro Baez. (2019). Natural disasters.Critical Care Clinics, 35, 591-607.

Hungerford, H. R., \& Trudi L. Volk. (2013). Changing learner behavior through environmental education. The Journal of Environmental Education, 8-21.

Kashdan, Todd, B., David J. Disabato, Fallon R. Goodman, \& Patrick E. McKnight. (2020). The Five-Dimensional Curiosity Scale Revised (5DCR): Briefer subscales while separating overt and covert social curiosity. Personality and Individual Differences, 157, 1-10.

Laal, Marjan, \& Mozhgan Laal. (2012). Collaborative learning: What is it? Procedia Social and Behavioral Sciences, 31, 491-495.

Luthfia, Ayu Azanella. (2019). Throughout 2019, BNPB Records 3,721 Natural Disasters Happened in Indonesia, https://www.kompas .com/tren/ $\mathrm{read} / 2019 / 12 / 23 / 183700665 /$ sepanjang2019-bnpb-catat-3.721-bencana-alamterjadi-di-indonesia?page=all. Accessed on March 21, 2020, Indonesia Time: 14.17 WIB.

Merkt, Martin., Sonja Weigand, Anke Heier, \& Stephan Schwan. (2011). Learning with videos vs. learning with print: The role of interactive features. Learning and Instruction, 21, 687-704.

Metzger, Tina \& Douglas Mc Ewen. (2010). Measurement of environmental sensitivity. The Journal of Environmental Education, 30, 38-39.

Moa, Xiaorong, Olivia Wai Man Funga, Xiuying Huc, \& Alice Yuen Lokea. (2018). Psychological impacts of disaster on 
rescue workers: A review of the literature. International Journal of Disaster Risk Reduction, 27, 602-617.

Moore, Raeanne, C., Sheena I. Deva, Dilip V. Jestea, Isabel Dziobek, \& Lisa T. Eyler. (2015). Distinct neural correlates of emotional and cognitive empathy in older adults. Psychiatry Research: Neuroimaging, $232,42-50$.

Nasir, Abdur Rehmann, \& Hans Joachim Bargstad. (2017). An approach to develop video tutorials for construction tasks. Procedia Engineering, 196, 1088-1097.

Saiman, Kathleen, Sushila Sinnatamby, Laily Mastura Mustafa, Norlidah Alias, \& Saedah Siraj. (2013). Impact of video on learning in students with autism in Malaysia: Future prospects. Procedia Social and Behavioral Sciences, 103, 459-466.

Samarasekara, Ratnayakage Sameera Maduranga, Jun Sasaki, Miguel Esteban \& Hirotaka Matsuda. (2017). Assessment of the co-benefits of structures in coastal areas for tsunami mitigation and improving community resilience in Sri Lanka. International Journal of Disaster Risk Reduction, 23, 80-92.

Sangha, Kamaljit K., Jeremy Russell Smith, Jay Evans \& Andrew Edwards. (2020). Methodological approaches and challenges to assess the environmental losses from natural disasters. International Journal of Disaster Risk Reduction, 49, 1-12.
Shoji, Masahiro, Yoko Takafuji, \& Tetsuya Harada. (2020). Behavioral impact of disaster education: Evidence from a dancebased program in Indonesia. International Journal of Disaster Risk Reduction, 45, 1-13.

Sivek, Daniel J. (2010). Environmental sensitivity among Wisconsin High School students. Environmental Education Research, 8, 155-170.

Sun, Pei Chen \& Hsing Kenny Cheng. (2007). The design of instructional multimedia in e-Learning: A media richness theory-based approach. Computers \& Education, 49, 662-676.

Tamagnone, Paolo, Elena Comino, \& Maurizio Rosso. (2020). Rainwater harvesting techniques as an adaptation strategy for flood mitigation. Journal of Hydrology, $586,1-35$.

Titaya, Sararit. (2016). Analyze on effect and building regulation in Northern Thailand's earthquake, May 2014 Chiangmai's residents risk perception and response to earthquake. Procedia Social and Behavioral Sciences, 218, 85-94.

Van Der Meij, Hans, \& Jan van der Meij. (2014). A comparison of paper-based and video tutorials for software learning. Computers \& Education, 78, 150-159.

Zou, Maria Li., Mandy Xiaoyang Li, \& Vincent Cho. (2020). Depression and disclosure behavior via social media: A study of university students in China. Heliyon, 6, $1-10$. 